\title{
5. NZ watchdogs must keep up with media's changing face
}

\section{COMMINIIARY}

A discussion paper released by the New Zealand Law Commission just before the end of 2011 looked into how well the regulatory framework governing the NZ media was working, and concluded that change was needed. Currently complaints must be made first to the publication or broadcaster concerned. Only if the complainant is dissatisfied with the outcome is there a right of appeal to the self-regulatory Press Council, for print media, or, for radio and television, to the statutory Broadcasting Standards Authority (BSA). The commission's recommendation is for a new single regulator created by statute to which all complaints about 'news media' would be directed. Unlike the Press Council or the BSA, the new regulator could intervene without any complaint being laid and-possibly - even before a story is published where there are concerns about the methods the journalist used to gather information. And, importantly, online media would be included. But debate about the issues in New Zealand have been rather muted compared to the Australian and British debates.

\section{LINDA CLARK}

Former journalist and public law specialist

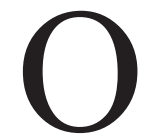

PENING the first public session of the inquiry into the culture and ethics of the British press, Lord Justice Leveson said that at the inquiry's heart was one simple question: 'Who guards the guardians?' That same question is being asked by the Law Commission in New Zealand, although without the star-studded roll call of witnesses and their high-voltage claims of harassment and harm from the British tabloids.

A discussion paper released by the commission just before the end of 2011 looked into how well the regulatory framework governing the New Zealand media was working, and concluded that change was needed. New Zealand media - both print and broadcast-regulate themselves to a degree. Both have codes of practice which emphasise the need for accuracy, fairness and 
balance. For print journalists this is entirely voluntary; for broadcast journalists the main tenets of the code are set down in the Broadcasting Act 1989. Complaints must be made first to the publication or broadcaster concerned. Only if the complainant is dissatisfied with the outcome is there a right of appeal to the Press Council, for print media, or to the Broadcasting Standards Authority (BSA).

But this compartmentalised approach is outdated as the demarcation between print and broadcast media no longer applies. Newspapers have websites posting video, and television and radio channels have websites posting text. In the field, print journalists film video and television journalists go back to their desks and write blogs.

It is a technological and content blur, and the regulations have not kept up. A complaint about an unfair or inaccurate story on TV3 will be considered by the BSA, but the same story on TV3's website will not. Material shown on the internet is outside the BSA's jurisdiction.

The Press Council has extended its jurisdiction to include audiovisual content on its members' websites but it too faces problems. Should it order the removal of potentially damaging content from web archives years after the original story's news value has passed? Should complaints be accepted beyond the normal 30-day limitation if the material is still available online? Do online stories have a different standard of fairness and balance?

Then there is a whole world of bloggers and citizen journalists who compete with, complement and often feed the traditional news stream. These 'journalists' - ranging from those who look and act like mainstream media to those who simply vent - currently answer to no one.

The commission's solution was a new single regulator created by statute to which all complaints about 'news media' would be directed. Unlike the Press Council or the BSA, the new regulator would intervene without any complaint being laid and - possibly — even before a story is published where there are concerns about the methods the journalist used to gather information.

The commission recommended an 'independent panel' to appoint members of the new body, with the majority being from outside the industry. It is not clear who would appoint this panel or that such a convoluted appointment process is required. Judges and regulators such as New Zealand's Commerce Commissioner (who 'polices' takeovers and mergers) are appointed by the Governor-General on the recommendation of a minister; none have proved to be toadies. 
A substantial part of the commission's report wrestled with the question of 'who is a journalist?'. Is the mad keen blogger providing blow by blow posts of the day's political machinations a journalist, subject to the same public expectations of fairness and accuracy and balance? And, if so, how then to distinguish between that class of blogger and the less prolific, less 'newsy' variety?

In the end the commission offered a range of qualifying criteria and then opted for two possible options - one voluntary, the other compulsory. Under the first, media 'outlets' would elect to be subject to the new regulator in return for the privileges and exemptions granted to the news media. These privileges include access to Parliament and the courts, and special rights under the Privacy Act, the Copyright Act, the Defamation Act and the Human Rights Act.

The commission was hedging its bets that online news services or aggregators would want to opt in, since they already operate much like regular media and there would be brand and credibility advantages in being part of the club. A calculation that there was enough access/brand advantage to be leveraged off being part of this new establishment would determine whether any individual bloggers agreed to subject themselves to regulation in this way. Frankly for most bloggers it would not be worth the bother. In most cases freedom from any constraints to be balanced and fair is an important part of a blogger's own brand.

The alternative model - compulsion - has other problems, most notably how to draw a line between those media who must be regulated and those who could remain unregulated. The commission accepted this was tricky- the end result might even be the status quo.

The commission's recommendations have now gone out for consultation with the public. Just 70 submissions were received. From media organisations, curiously the print media supported a one size for all single regulator; broadcast media did not — although all media favoured a voluntary regime. The broadcast media (both free to air and pay) collaborated to recommend a third way forward, whereby the industry itself would establish a new Online Media Standards Authority to mop up all those complaints that currently have nowhere to go. At the time of writing those organisations were actively working behind the scenes to get this new self-regulating body up and running. Its founding principles had been drafted and an independent chair was being sought. 
The print media have also been looking at ways to beef up the Press Council. Attempts by some in print to have the Press Council expand its ambit to cover broadcast media's online content were roundly rebuffed. Clearly, the threat of tougher regulation has focused minds. The commission's recommendation was not perfect but it was a thoughtful attempt to wrestle with the challenges of the new media. Not surprisingly it ran into resistance from media organisations, many of which equate any centrally-controlled regulation with state interference. Governments, as any journalist will attest, cannot be trusted to keep their fingers out.

For the most part though the media have been greatly assisted by the John Key-led National government in this instance. The push to tighten media regulation came in the last term from a young and reformist Cabinet Minister who has since left politics for a career in the banking sector. His colleagues may be less inclined to buy a fight. And frankly the public has not shown any appetite for the issue.

New Zealanders like to complain about the media. Who doesn't? The BSA receives more than 250 complaints each year (and each of those has already been through the broadcaster's internal complaints system). But the New Zealand media has not yet demonstrated anything like the excesses that have been the focus of the Leveson inquiry. For the most part its sins are sins of omission, rather than commission and as such the debate about media ethics lacks heat.

Which means the government can afford to sit back and watch what happens in the UK and in Australia. It can allow the broadcasters to experiment with an extra layer of self-regulation. It can wait to see what changes the Law Commission makes when it issues its final report later this year. Interestingly the commission's initial report also included separate recommendations aimed at responding to the harm caused by citizens using the media. This part of the report, about which the public has strong views and sensitivities after a number of high profile cyber-bullying tragedies, has been picked up by government and raced into policy.

While there is no such political urgency to regulate the media the commission is likely to stick to its guns and recommend streamlining and strengthening. The rapid convergence both of form and content makes the current multiplicity of regulators expensive and cumbersome. Media organisations aren't ready to accept this yet. But change will come. 
In any case there are other undercurrents brewing. Like media organisations everywhere, New Zealand's mainstream media is cash-strapped and struggling to adapt to the changes that come with online demands. At the same time the government has stripped the state-owned television channel Television New Zealand (previously the most dominant media player) of any public service obligations. In many respects, mainstream media is fighting for relevance and as it shouts louder to get the attention of readers, listeners and viewers it strains the long-established bonds with its audience. A less loyal audience is likely to be less tolerant of ethical missteps; and ultimately more interested in seeing the watchdogs watched over.

Former TVNZ political editor Linda Clark is a lawyer and consultant at Chapman Tripp law firm. The views presented here are her own and were first published by The New Zealand Herald and Pacific Media Centre Online. linda.clark@chapmantripp.com

\section{Reference}

NZ Law Commission (2011). NZLC IP27. The news media meets 'new media': Rights, responsibilities and regulation in the digital age. Retrieved on 20 January 2012, from www.lawcom.govt.nz/project/review-regulatory-gaps-and-new-media 
Copyright of Pacific Journalism Review is the property of Auckland University of Technology and its content may not be copied or emailed to multiple sites or posted to a listserv without the copyright holder's express written permission. However, users may print, download, or email articles for individual use.

http://www.aut.ac.nz/depts/commstud/journ/pjrsubs.shtml 